\title{
The analysis of heating process of catalytic converter using thermo-vision
}

\author{
The article tackles the issues related to a process of heating of three way catalytic converter during the cold start and \\ the heating of the spark ignition engine. The measurements on the test bench were performed, taking into consideration \\ how engine works directly after the start, on the idle speed and under the load, during which the temperature of the exhaust \\ gases in the exhaust system and coolant on the cylinder head were measured. At the same time the track of the heat state \\ of the catalytic converter was monitored using thermo-vision camera. The results of the measurements were presented \\ as charts and selected thermo-grams, qualitatively representing the issue of heating of the catalytic converter.
}

Key words: internal combustion engine, catalytic converter, thermo-vision

\section{Analiza procesu nagrzewania reaktora katalitycznego przy użyciu termowizji}

\begin{abstract}
W artykule omówiono zagadnienia związane z procesem nagrzewania trójfunkcyjnego reaktora katalitycznego podczas zimnego rozruchu i nagrzewania silnika spalinowego ZI. Przeprowadzono pomiary na stanowisku hamowni, uwzględniając pracę silnika bezpośrednio po rozruchu, na biegu jałowym oraz obciążonego, w czasie których mierzono temperaturę spalin w układzie wylotowym i cieczy w glowicy silnika, równocześnie prowadząc zapis stanu cieplnego reaktora katalitycznego przy użyciu kamery termowizyjnej. Wyniki pomiarów przedstawiono w postaci wykresów oraz wybranych termogramów, obrazujących jakościowo zagadnienie nagrzewania się reaktora katalitycznego.
\end{abstract}

Słowa kluczowe: silnik spalinowy, reaktor katalityczny, termowizja

\section{Introduction}

In Europe, passenger vehicles are mainly operated in city traffic, characterized by short trips at low speeds and frequent stops and starts. The majority of trips are realized on distances below $5 \mathrm{~km}$ and in approx. $30 \%$ of cases even below $2 \mathrm{~km}[1]$. Such conditions are not optimal for the engine (cold starts, operation at idle, operation at low loads and frequently varying engine speeds and loads). This results in a long engine heating time and operation under non-steady thermal conditions, the consequence of which is increased fuel consumption and exhaust emissions.

Increasing the maximum temperature of the coolant is one of many methods to improve the energy conversion contained in the fuel into effective [14]. Under city traffic conditions, when the engine operates at low loads or at idle, the time necessary to obtain the optimum coolant temperature is prolonged. The optimum engine oil temperature is even more difficult to obtain. Oil temperature depends not only on the heat generated in the combustion chamber but also on the coolant flow rate resulting directly from the engine speed [2]. Consequently, the overall engine efficiency deviates from the optimum and the fuel consumption is increased. This increases the emission of carbon dioxide $\left(\mathrm{CO}_{2}\right)$, carbon monoxide $(\mathrm{CO})$ and hydrocarbons $(\mathrm{HC})$, particularly at cold starts when the mixture is additionally enriched.

The above-mentioned conditions are also far from optimum for the operation of the catalytic converter, whose temperature needed for proper operation must exceed $300^{\circ} \mathrm{C}$ $[1,6,7]$. Besides, the operation of a catalytic converter in a chemically aggressive environment and at variable temper-

\section{Wstęp}

W Europie samochody osobowe eksploatowane są głównie w ruchu miejskim, dla którego charakterystyczne jest pokonywanie krótkich dystansów z małą prędkością, częste zatrzymywanie i ruszanie pojazdu. Znaczna liczba przejazdów występuje na odcinkach poniżej $5 \mathrm{~km}$, a w około $30 \%$ przypadków nawet na odcinkach mających mniej niż $2 \mathrm{~km}$ [1]. Oznacza to dla silnika spalinowego pracę w nieoptymalnych warunkach, a mianowicie podczas zimnego rozruchu, na biegu jałowym oraz z małymi obciążeniami i częstymi zmianami zarówno prędkości obrotowej, jak i obciążenia. Skutkuje to długim czasem nagrzewania silnika i pracą $w$ nieustalonym stanie cieplnym, czego następstwem jest zwiększone zużycie paliwa oraz zwiększona emisja toksycznych składników spalin.

W dążeniu do poprawy sprawności przetwarzania energii zawartej w paliwie na pracę efektywną jednym $\mathrm{z}$ wielu działań jest zwiększanie dopuszczalnej temperatury cieczy chłodzącej [14]. Jednocześnie w warunkach miejskich, kiedy silnik pracuje przeważnie z małymi obciążeniami lub na biegu jałowym, czas osiągnięcia optymalnej temperatury cieczy chłodzącej jest znacznie wydłużony. Jeszcze trudniejsze jest osiągnięcie nominalnej temperatury pracy oleju, która zależy nie tylko od ciepła wydzielanego w komorze spalania, ale również od intensywności przepływu cieczy chłodzącej wynikającej z prędkości obrotowej silnika [2]. W efekcie sprawność ogólna silnika odbiega od nominalnej, więc zużycie paliwa jest zwiększone. Oznacza to zwiększenie emisji dwutlenku węgla $\left(\mathrm{CO}_{2}\right)$, a także tlenku węgla $(\mathrm{CO})$ i węglowodorów (HC), szczególnie przy zimnym rozruchu, kiedy mieszanka jest dodatkowo wzbogacana. 
atures leads to aging caused by thermal and chemical deactivation, thus leading to a reduction of the device conversion rate and an increase in the light-off temperature [6, 7].

The results of the exhaust emissions measurements performed under the New European Driving Cycle (NEDC) conditions clearly show that during cold start (UDC cycle), before the catalytic converter reaches light-off, approx. $80 \%$ of the $\mathrm{HC}$ and approx. $90 \% \mathrm{CO}$ are generated $[1,6]$.

In the first stage after engine start, high heat losses (exhaust system) occur due to increased heat exchange between the exhaust gas and the cold components of the engine. The catalytic converter, owing to its high thermal capacity, absorbs much greater heat from the exhaust gas than the duct between the exhaust manifold and the converter [11]. The temperature increase rate in the heating phase is decisive of the catalytic converter efficiency, hence, from the emission point of view, it is better that the engine operates under load immediately after cold start $[1,2,10,11]$.

Literature provides that the inner temperature of the catalytic converter corresponding to its light-off is approx. $300{ }^{\circ} \mathrm{C}$. Nevertheless, the specific flow of the exhaust gas, the design of the converter and the occurring chemical reactions (oxidation) generates a temperature gradient in the radial and axial direction, which is why the measurements of the temperature distribution were performed with a thermographic camera allowing for the heating process of the converter under varied engine conditions of operation.

\section{Measurement stand}

The measurements were performed on an engine dynamometer fitted with a straight four-cylinder spark ignition engine (Fiat 170A1.00) of the displacement of $900 \mathrm{~cm}^{3}$. The engine exhaust system was fitted with a serially manufactured three-way catalytic converter. In an insulated catalytic converter casing, two ceramic support monoliths were fitted of a circular cross-section (diameter of approx. $90 \mathrm{~mm}$ ) and the length of approx. $75 \mathrm{~mm}$ each, divided by a gap of approx. $8 \mathrm{~mm}$. The distance between the exhaust manifold and the catalytic converter was 250 $\mathrm{mm}$. During the measurements, the engine was fueled with unleaded fuel (LO 95).

Due to the specific purpose of the investigations the temperature was measured at three points of the exhaust systems: exhaust manifold and the points upstream and downstream of the catalytic converter. The coolant temperature in the cylinder head was also measured serving the purpose of validation of the engine temperature and intake air temperature monitoring the ambient conditions (engine operating conditions). The temperature measurements were performed with $\mathrm{K}$ thermocouples and the results were continuously recorded by Agilent 34972A with the measurement resolution of $1 \mathrm{~s}$.

The recording of the thermal state of the catalytic converter was realized with a thermographic camera (Flir T335). Prior to the measurement, the following parameters were set in the camera: ambient temperature, equivalent ambient temperature, thermal emission rate of the tested
Nie są to również optymalne warunki pracy dla reaktora katalitycznego, który do prawidłowego działania wymaga temperatury wewnętrznej powyżej $300^{\circ} \mathrm{C}[1,6,7]$. Ponadto w wyniku eksploatacji reaktora w środowisku agresywnym chemicznie i przy zmieniających się wartościach temperatury następuje z czasem jego starzenie w wyniku dezaktywacji termicznej i chemicznej, powodujące, iż stopień konwersji toksycznych składników spalin się zmniejsza, natomiast temperatura początku działania reaktora ulega zwiększeniu $[6,7]$.

Wyniki pomiarów emisji limitowanych toksycznych składników spalin wykonywanych podczas europejskiego testu jezdnego (NEDC) jednoznacznie wskazują, że podczas zimnego rozruchu silnika (cykl UDC), zanim reaktor katalityczny osiągnie temperaturę pracy, powstaje około $80 \% \mathrm{HC}$ oraz około $90 \%$ CO $[1,6]$.

W pierwszej fazie po uruchomieniu silnika następują duże straty ciepła zawartego w spalinach, wynikające ze wzmożonej wymiany ciepła między zimnymi elementami silnika znajdującymi się na drodze przepływu spalin a spalinami. Reaktor katalityczny ze względu na dużą pojemność cieplną powoduje znacznie większy spadek temperatury spalin niż przewód znajdujący się między kolektorem wylotowym a reaktorem [11]. Szybkość narastania temperatury w fazie nagrzewania silnika decyduje o efektywności działania reaktora katalitycznego, dlatego z punktu widzenia zmniejszania emisji toksycznych składników spalin korzystniejsza jest praca silnika po uruchomieniu z obciążeniem $[1,2,10,11]$.

W literaturze tematu podaje się, iż temperatura wewnętrzna reaktora katalitycznego odpowiadająca początkowi działania wynosi około $300{ }^{\circ} \mathrm{C}$. Niemniej jednak charakter napływu spalin do reaktora, jego budowa oraz zachodzące w nim reakcje utleniania będą generować gradient temperatury zarówno w kierunku promieniowym, jak i osiowym. $\mathrm{Z}$ tego względu przeprowadzono pomiary rozkładu temperatury w reaktorze katalitycznym przy użyciu kamery termowizyjnej, uwzględniając proces nagrzewania urządzenia w różnych warunkach pracy silnika spalinowego.

\section{Stanowisko pomiarowe}

Pomiary wykonano na stanowisku hamowni silnikowej, na którym zamontowany jest czterocylindrowy rzędowy silnik spalinowy o zapłonie iskrowym Fiat 170A1.00, o objętości skokowej $900 \mathrm{~cm}^{3}$. W układzie wylotowym silnika znajduje się trójfunkcyjny reaktor katalityczny, który był stosowany w seryjnej produkcji silnika. W izolowanej obudowie reaktora umieszczone są dwa ceramiczne monolity rdzenia o przekroju kołowym (średnica około $90 \mathrm{~mm}$ ) i o długości około $75 \mathrm{~mm}$ każdy, rozdzielone szczeliną o długości około $8 \mathrm{~mm}$. Odległość między kolektorem wylotowym a reaktorem katalitycznym wynosi $250 \mathrm{~mm}$. Podczas pomiarów silnik był zasilany benzyną bezołowiową o LO 95 .

Ze względu na cel pracy mierzono temperaturę spalin w trzech punktach układu wylotowego, a mianowicie w kolektorze wylotowym oraz przed i za reaktorem katalitycznym. Ponadto pomiarowi podlegała temperatura cieczy chłodzącej w głowicy silnika, służąca weryfikacji stopnia 
object, air humidity and distance from the tested object [5]. The main measurements were preceded by preliminary measurements consisting of the determination of the thermal emission rate on the surface of the elements on which the thermal state was recorded (the determined emission coefficient was $\varepsilon=0.75$ ) and determining appropriate temperature ranges and operating parameters of the thermographic camera.

Additionally, the excess air coefficient $\lambda$ was measured and recorded along with the exhaust gas composition downstream of the catalytic converter with a 5 gas analyzer (Capelec CAP 3201).

\section{Thermographic measurements}

Thermography is currently perceived as one of the most interesting diagnostic-observation methods. It has found application in energy production, building industry, metallurgy, environment protection and medicine to name only a few $[3,4,8,9]$. The wide application of thermography results from a variety of advantages that systems based on object thermal analysis have. One of such important advantages is contactless measurement of the tested objects, which in most applications, is the basic criterion for the use of thermographic technology.

Thermography utilizes the emission of electromagnetic radiation by every object whose temperature is higher than absolute zero. The electromagnetic spectrum is divided into areas of wavelengths that are distinguished by methods used for the detection of radiation. There is no fundamental difference between radiation in different bands of electromagnetic spectrum. They are all subject to the same laws and the only difference is the wavelength. In thermographic research, a part of the electromagnetic spectrum is used in the infrared range that is divided into four smaller subranges otherwise known as near $(0.75-3 \mu \mathrm{m})$, mid $(3-6 \mu \mathrm{m})$, far $(6-15 \mu \mathrm{m})$ and very far (15-100 $\mu \mathrm{m})$ infrared [12].

The value of the radiated energy grows as the temperature of the object increases, which enables the measurement of its temperature by measuring the values of the infrared radiation. The intensity of the electromagnetic radiation depends on the temperature and specific features of the object surface [13]. The obtained thermogram is a reproduction of the temperature distribution on the surface of the observed object.

Thermographic cameras are devices for the measurement of the energy of a given object. They are composed of an optical system, infrared radiation detector (with a cooling system used in more expensive units) and electronic amplification, processing and visualization equipment. Depending on the spectral range, in which cameras operate we may distinguish short-wave ( 3 to $5 \mu \mathrm{m}$ ) and long-wave ( 8 to $15 \mu \mathrm{m}$ ) cameras.

A Flir T335 thermographic camera was used for the measurements, whose results have been presented in this paper. It is a modern measurement device for contactless remote measurement of temperature and its distribution on the object (thermographic imaging). The operating temperature range of the camera is $-20 \ldots+650{ }^{\circ} \mathrm{C}$ and the temperature measurement error: $\pm 2{ }^{\circ} \mathrm{C}, \pm 2 \%$ of the measurement value. nagrzania silnika, a także temperatura w układzie dolotowym do kontroli warunków na stanowisku pomiarowym (warunków pracy silnika). Pomiary temperatury wykonywano za pomocą termopar typu $\mathrm{K}$, a wyniki pomiarów rejestrowano urządzeniem Agilent 34972A w sposób ciągły z krokiem pomiarowym $1 \mathrm{~s}$.

Równolegle prowadzono rejestrację stanu cieplnego reaktora katalitycznego za pomocą kamery termowizyjnej Flir T335. Przed przystapieniem do pomiaru ustawiono w kamerze termowizyjnej wartość temperatury otoczenia, zastępczej temperatury otocznia, emisyjność badanego obiektu, wilgotność powietrza oraz odległość od badanego obiektu [5]. Z tego powodu zasadnicze pomiary były poprzedzone pomiarami wstępnymi, polegającymi na wyznaczeniu emisyjności powierzchni elementów, na których rejestrowano stan cieplny (wyznaczony współczynnik emisyjności wyniósł $\varepsilon=0,75$ ), a także ustaleniu właściwych, do analizowanych zakresów temperatury, parametrów pracy kamery termowizyjnej.

Dodatkowo mierzono i zapisywano współczynnik nadmiaru powietrza $\lambda$ oraz skład spalin za reaktorem katalitycznym przy użyciu pięciogazowego analizatora spalin typu Capelec CAP 3201.

\section{Pomiary termowizyjne}

Termowizja uważana jest obecnie za jedną z najbardziej interesujących metod diagnostyczno-obserwacyjnych. Znalazła zastosowanie w energetyce, budownictwie, hutnictwie, badaniach środowiska, medycynie i wielu innych dziedzinach $[3,4,8,9]$. Szerokie zastosowanie termowizji wynika $\mathrm{z}$ wielu zalet, jakie mają systemy pomiarowe oparte na analizie termicznej badanych obiektów. Jedną z nich jest bezkontaktowy pomiar badanych obiektów, co w większości zastosowań jest podstawowym kryterium decydującym o wykorzystaniu technik termowizyjnych.

W badaniach termowizyjnych wykorzystuje się zjawisko emisji promieniowania elektromagnetycznego przez każde ciało, którego temperatura jest wyższa od zera bezwzględnego. Widmo elektromagnetyczne jest podzielone na wiele obszarów długości fal, które rozróżniane są przez metody wykorzystywane do detekcji promieniowania. Nie ma zasadniczej różnicy pomiędzy promieniowaniem w różnych pasmach widma elektromagnetycznego. Wszystkie one podlegają tym samym prawom i różnią się jedynie długością fali. W badaniach termograficznych wykorzystuje się część widma elektromagnetycznego $\mathrm{w}$ zakresie podczerwieni, które jest często dzielone na cztery mniejsze podzakresy, umownie określone jako podczerwień bliska $(0,75-3 \mu \mathrm{m})$, średnia $(3-6 \mu \mathrm{m})$, daleka $(6-15 \mu \mathrm{m})$ oraz bardzo daleka $(15-100 \mu \mathrm{m})$ [12].

Wartość wypromieniowanej energii rośnie ze wzrostem temperatury obiektu, co umożliwia pomiar jego temperatury przez pomiar wartości emitowanej energii, szczególnie w paśmie promieniowania podczerwonego. Intensywność promieniowania elektromagnetycznego zależy od temperatury i cech powierzchni ciała [13]. Otrzymany termogram jest odwzorowaniem rozkładu temperatury na powierzchni obserwowanego obiektu. 
The applied camera was fitted with a microbolometric matrix with the resolution of $320 \times 240$ pixels, $25^{\circ} \times 18.75^{\circ}$ lens and had the sensitivity of N.E.T.D. $0.05^{\circ} \mathrm{C}$.

\section{Results and analysis}

Based on the preliminary measurements, the engine operation during the heating process was monitored at coldstart at idle with the engine speed of $2000 \mathrm{l} / \mathrm{min}$ and a load of approx. $50 \%$ of the rated value $(30001 / \mathrm{min}, 30 \mathrm{~N} \cdot \mathrm{m})$.

All graphs presented in this paper contain results as a function of time. Based on the analysis of the coolant temperature and exhaust gas, the presented values have been limited to the first $1200 \mathrm{~s}$ of the measurements.

The temperature values of the coolant in the cylinder head and the intake air for the engine at idle and under load respectively have been presented in Fig. 1. Fig. 2 presents the values of temperature of the exhaust gas in the exhaust manifold as well as downstream and upstream of the catalytic converter for both states of engine operation.

The engine temperature was validated by the coolant temperature in the cylinder head. For the engine at idle, the temperature of the initiation of thermostat opening was reached after approx. $700 \mathrm{~s}$ and full thermostat opening occurred after $1200 \mathrm{~s}$ of engine operation. For the engine under load, the time of initiation of the thermostat opening was approx. $350 \mathrm{~s}$ shorter and stable operating conditions at full thermostat opening were obtained after $700 \mathrm{~s}$.

Upon engine start the air fuel mixture is enriched to ensure proper engine operation despite condensation of fuel on the walls of the intake manifold and cylinders and its reduced evaporation. Then, the mixture is leaned, which is reflected in the course of the exhaust gas temperature in the exhaust manifold and upstream of the catalytic converter in the initial period of engine operation. Besides, on the distance of approx. $250 \mathrm{~mm}$ between the measurement point in the exhaust manifold and the point in the pipe immediately upstream of the catalytic converter, the temperature decreases by approx. $100{ }^{\circ} \mathrm{C}$, which is a result of heat transfer to the cold walls of the exhaust pipe. The exhaust gas temperature measured downstream of the catalytic converter is rather constant and amounts to approx. $50{ }^{\circ} \mathrm{C}$ for $50-60 \mathrm{~s}$, despite a very rapid temperature increase of the exhaust gas upstream of the catalytic converter. This indicates an intense heat transfer from the exhaust gas to the converter supports. At this time, the exothermal reactions of oxidation of $\mathrm{CO}$ an $\mathrm{HC}$ do not take place. Assuming that the temperature downstream of the catalytic converter is close to the temperature of the monoliths, when the engine operated at idle the exhaust gas temperature downstream of the catalytic converter reached $300{ }^{\circ} \mathrm{C}$ after $200 \mathrm{~s}$ and the corresponding exhaust gas temperature upstream of the catalytic converter was $425{ }^{\circ} \mathrm{C}$. For the engine under load, the exhaust gas downstream of the catalytic converter reached $300{ }^{\circ} \mathrm{C}$ after $85 \mathrm{~s}$ and the temperature upstream of the catalytic converter at that time was $560{ }^{\circ} \mathrm{C}$.

Ceramic monoliths heat up longer than the metal ones, which is disadvantageous in the engine heating phase. At the same time, they release less heat to the environment
Urządzeniami do pomiaru energii badanego obiektu są kamery termowizyjne, składające się z układu optycznego, detektora promieniowania podczerwonego wraz $\mathrm{z}$ odpowiednim układem chłodzenia, zastosowanym w droższych modelach kamer, elektronicznego toru wzmacniania, przetwarzania i wizualizacji. Zależnie od zakresu spektralnego, w którym działają, kamery termowizyjne dzieli się na krótkofalowe (zakres pracy 3 do $5 \mu \mathrm{m}$ ) i długofalowe ( 8 do $15 \mu \mathrm{m})$.

Do pomiarów, których wyniki są zawarte w tym artykule, użyto kamery termowizyjnej typu Flir T335. Jest ona nowoczesnym urządzeniem pomiarowym służącym do bezkontaktowego, zdalnego pomiaru temperatury i za pomocą zdjęć termowizyjnych do analizy jej rozkładu na badanym obiekcie. Zakres temperatury pracy kamery wynosi: $-20 \ldots+650{ }^{\circ} \mathrm{C}$, a błąd pomiaru temperatury: $\pm 2{ }^{\circ} \mathrm{C}$, $\pm 2 \%$ wartości pomiaru. Zastosowana kamera jest wyposażona w matrycę mikrobolometryczną o rozdzielczości 320 $\times 240$ pikseli, obiektyw $25^{\circ} \times 18,75^{\circ}$ oraz charakteryzuje się czułością N.E.T.D. $0,05^{\circ} \mathrm{C}$.

\section{Wyniki pomiarów i analiza}

Na podstawie pomiarów wstępnych do pomiarów zasadniczych wytypowano pracę silnika podczas procesu nagrzewania po zimnym rozruchu na biegu jałowym, z prędkością obrotową silnika 2000 1/min, jak również z obciążeniem odpowiadającym około 50\% wartości nominalnej (3000 $1 / \mathrm{min}, 30 \mathrm{~N} \cdot \mathrm{m})$.

Wszystkie znajdujące się w tej pracy wykresy zawierają wyniki pomiarów w funkcji czasu, przy czym na podstawie analizy temperatury cieczy chłodzącej oraz spalin ograniczono przedstawiane wartości do pierwszych $1200 \mathrm{~s}$ pomiarów.

Wartości temperatury cieczy chłodzącej w głowicy oraz powietrza dopływającego do układu dolotowego silnika, odpowiednio dla pracy silnika na biegu jałowym oraz obciążonego, przedstawiają wykresy na rys. 1. Natomiast na rysunku 2 przedstawiono wartości temperatury spalin w kolektorze wylotowym, a także przed i za reaktorem katalitycznym dla obu trybów pracy silnika.

Stopień nagrzania silnika weryfikowano na podstawie temperatury cieczy chłodzącej w głowicy silnika. Dla silnika pracującego na biegu jałowym temperatura początku otwarcia termostatu została osiągnięta po około $700 \mathrm{~s}$, natomiast pełne otwarcie termostatu po $1200 \mathrm{~s}$ pracy silnika. Dla silnika obciążonego czas początku otwarcia termostatu był o około 350 s krótszy, a stabilne warunki pracy przy pełnym otwarciu termostatu zostały osiągnięte po $700 \mathrm{~s}$.

Bezpośrednio po uruchomieniu zimnego silnika występuje wzbogacenie mieszanki paliwowo-powietrznej, tak aby, pomimo wykraplania paliwa na zimnych ściankach kolektora dolotowego oraz komór spalania i utrudnionego odparowywania, zapewnić prawidłowe warunki pracy silnika. Następnie skład mieszanki jest zubożany, co odzwierciedla przebieg temperatury spalin w kolektorze wylotowym i przed reaktorem katalitycznym w początkowym okresie pracy silnika. Ponadto na odcinku około $250 \mathrm{~mm}$ między punktem pomiaru temperatury spalin w kolektorze wylotowym, a w rurze bezpośrednio przed 
a)

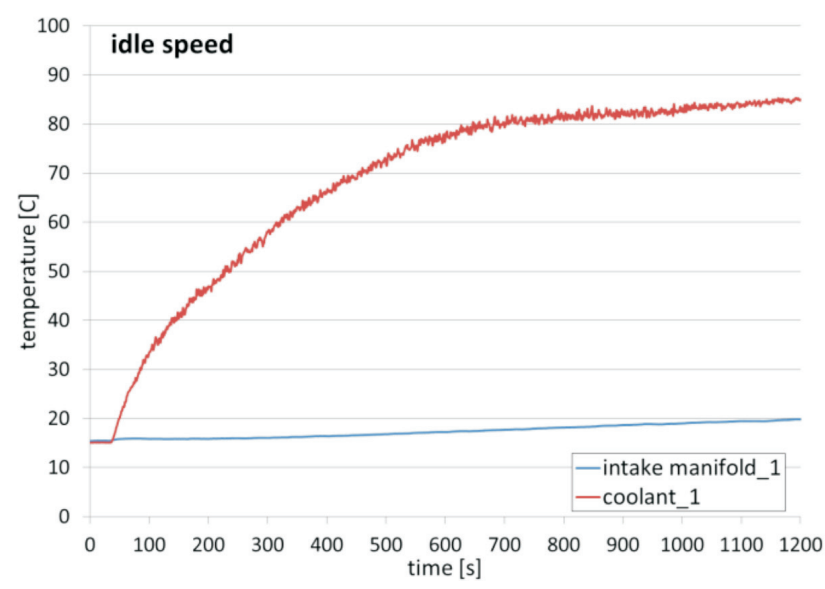

b)

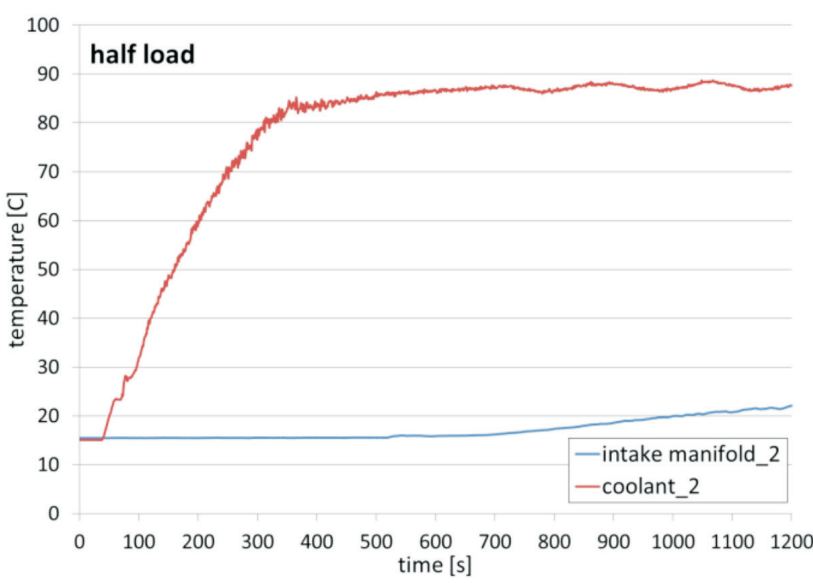

Fig. 1. Air temperature in intake manifold and coolant temperature in cylinder head: a) idle speed, engine speed $20001 / \mathrm{min}, \mathrm{b})$ load $30 \mathrm{~N} \cdot \mathrm{m}$, engine speed $30001 / \mathrm{min}$

Rys. 1. Temperatura powietrza w układzie dolotowym oraz temperatura cieczy w głowicy silnika: a) bieg luzem z prędkością obrotowa 2000 1/min, b) obciążenie $30 \mathrm{~N} \cdot \mathrm{m}$, prędkość obrotowa $3000 \mathrm{l} / \mathrm{min}$

and when they reach light-off it is easier to maintain proper parameters. These properties result from a lower heat transfer coefficient and higher specific heat of the ceramic monolith compared to the metal one [6].

Thermal stabilization of the exhaust gas (constant temperature difference) in the section between the exhaust manifold and inlet to the catalytic converter for idle speed took place after approx. $400 \mathrm{~s}$ and the difference was $45 \mathrm{~K}$, while for the engine under load this value was $300 \mathrm{~s}$ with the average temperature difference of $33 \mathrm{~K}$. Lower value of the temperature difference for the engine when under load was caused by a greater exhaust gas flow resulting from higher loads and engine speeds. The constant value of the temperature difference was recorded upstream and downstream of the catalytic converter starting from $700 \mathrm{~s}$ for idle speed and approx. $540 \mathrm{~s}$ for the engine under load. reaktorem wartość temperatury spalin zmniejsza się o około $100{ }^{\circ} \mathrm{C}$, co jest wynikiem oddawania ciepła do zimnych ścianek rury wylotowej. Temperatura spalin mierzona za reaktorem katalitycznym ma w przybliżeniu stałą wartość równą około $50{ }^{\circ} \mathrm{C}$ przez $50-60 \mathrm{~s}$, pomimo bardzo szybkiego wówczas zwiększania się wartości temperatury spalin przed reaktorem. Zależność taka wskazuje na intensywne oddawanie ciepła niesionego w spalinach do rdzeni reaktora. W tym czasie nie zachodzą egzotermiczne reakcje utleniania CO i HC. Zakładając, że temperatura spalin za reaktorem katalitycznym ma najbardziej zbliżone wartości do temperatury monolitów, podczas pracy silnika na biegu jałowym wartość $300^{\circ} \mathrm{C}$ spaliny za reaktorem osiągnęły po $200 \mathrm{~s}$, a odpowiadająca im temperatura spalin przed reaktorem wyniosła $425{ }^{\circ} \mathrm{C}$. W przypadku pracy silnika obciążonego spaliny za reaktorem uzyskały temperaturę $300^{\circ} \mathrm{C}$ a)

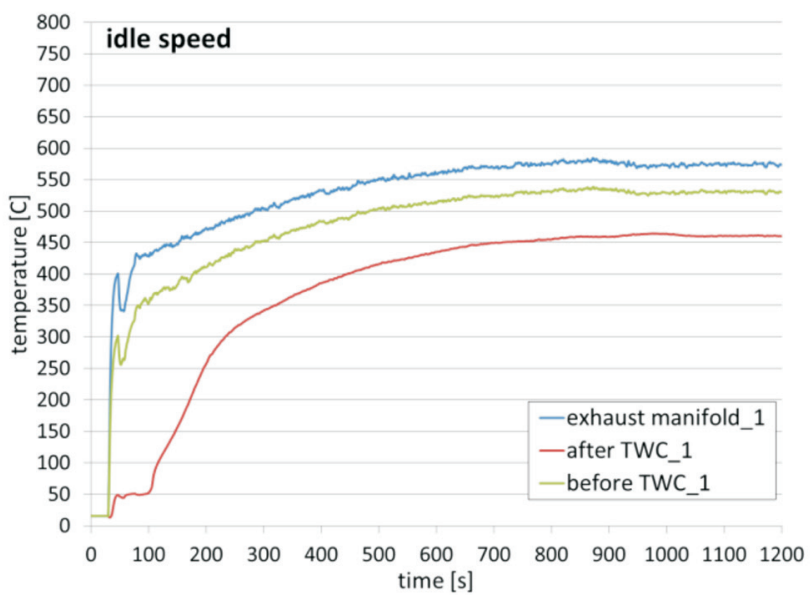

b)

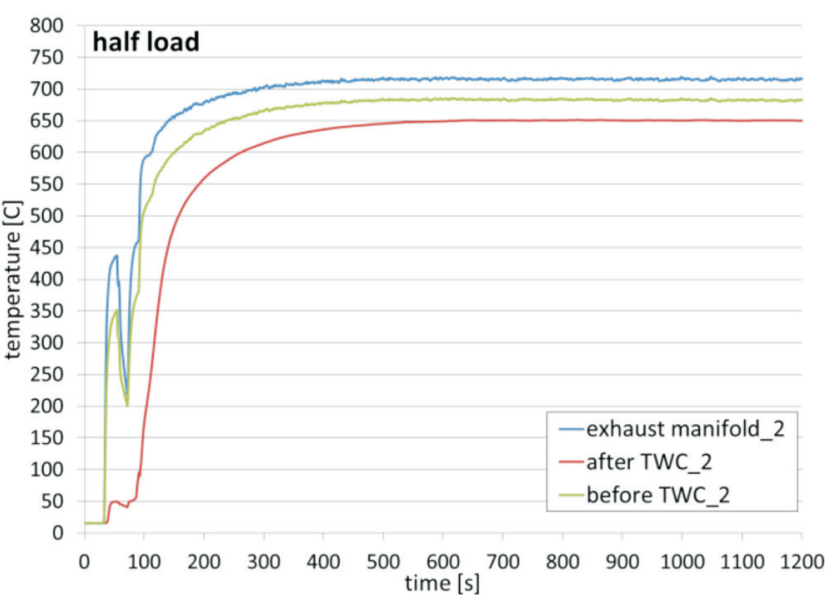

Fig. 2. Temperature of exhaust fumes in the exhaust manifold, before catalytic converter, behind catalytic converter: a) idle speed, engine speed $2000 \mathrm{1} / \mathrm{min}, \mathrm{b})$ load $30 \mathrm{~N} \cdot \mathrm{m}$, engine speed $3000 \mathrm{1} / \mathrm{min}$

Rys. 2. Temperatura spalin $w$ kolektorze wylotowym przed reaktorem katalitycznym, za reaktorem katalitycznym: a) bieg jałowy z prędkościa obrotowa $2000 \mathrm{l} / \mathrm{min}$, b) obciążenie $30 \mathrm{~N} \cdot \mathrm{m}$, prędkość obrotowa $3000 \mathrm{l} / \mathrm{min}$ 
a)

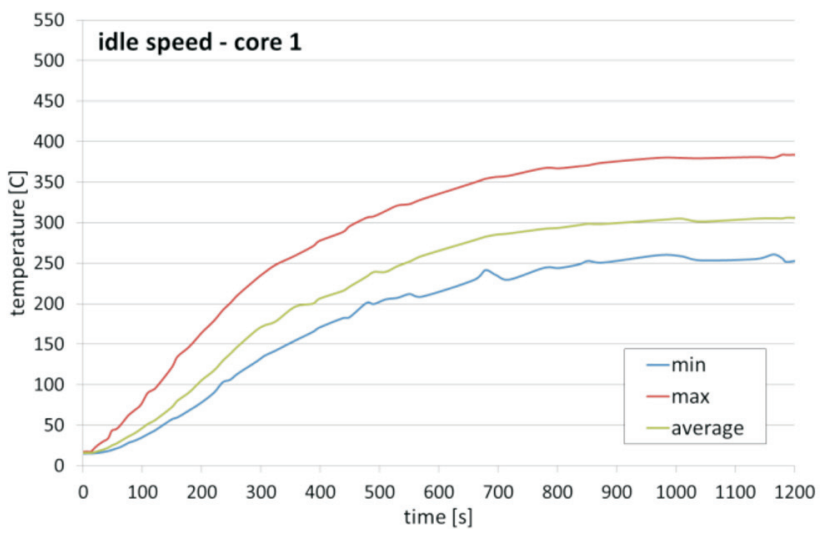

b)

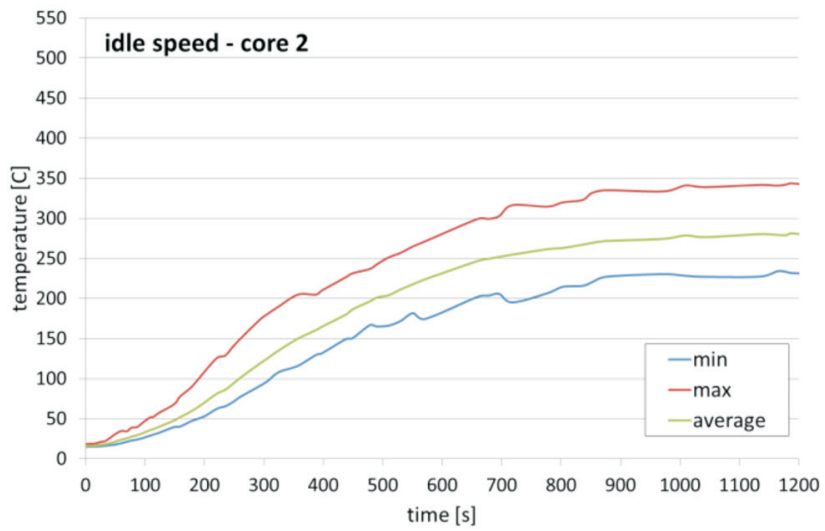

Fig. 3. Temperature of catalytic converter cores during heating of engine: a) on idle speed, b) engine speed 2000 1/min

Rys. 3. Temperatura rdzeni reaktora katalitycznego przy nagrzewaniu silnika: a) na biegu jałowym, b) z prędkościa obrotowa 2000 1/min

The constant temperature values for the three analyzed points of the exhaust system stabilized for idle speed after approx. $940 \mathrm{~s}$ and for the engine under load after approx. $540 \mathrm{~s}$.

Figures 3 and 4 contain values of temperature from the measurements performed with a thermographic camera, parallel to the measurement performed with thermocouples. On the thermograms, areas corresponding to the area of each of the two supports inside the converter were distinguished and the maximum, minimum and average values were recorded for a given surface. The distribution of temperature was not uniform, hence the average values are inclined towards the minimum ones. Additionally, according to the same procedure, the temperature values were read on the surface of the inlet diffuser, outlet confuser and the gap between the supports.

Stabilization of the temperatures on the surfaces of both supports took place after the same time - for the engine operating at idle this happened after approx. $900 \mathrm{~s}$ and for the engine under load after $700 \mathrm{~s}$. At the same time, for the other support, in the entire time range window under po $85 \mathrm{~s}$, a temperatura spalin przed reaktorem miała wówczas wartość $560{ }^{\circ} \mathrm{C}$.

Monolit ceramiczny dłużej się nagrzewa w porównaniu $\mathrm{z}$ monolitem metalowym, co jest niekorzystne $\mathrm{w}$ fazie nagrzewania silnika. Jednocześnie mniej ciepła oddaje do otoczenia, więc kiedy już osiągnie temperaturę pracy łatwiej utrzymywane są prawidłowe parametry. Właściwości te wynikają z mniejszego współczynnika przewodzenia ciepła oraz większego ciepła właściwego materiału monolitu ceramicznego niż monolitu metalowego [6].

Stabilizacja cieplna spalin (stała różnica temperatury) na odcinku między kolektorem wylotowym a wlotem do reaktora katalitycznego dla biegu jałowego nastąpiła po około $400 \mathrm{~s}$, a wartość różnicy wyniosła $45 \mathrm{~K}$, natomiast dla obciążonego silnika po $300 \mathrm{~s}$, ze średnią różnicą $33 \mathrm{~K}$. Mniejsza wartość różnicy temperatury dla silnika obciążonego spowodowana jest większym strumieniem spalin wynikającym z większego obciążenia silnika oraz większą prędkością przepływu spalin spowodowaną większą prędkością obrotową silnika. Między wlotem a wylotem $\mathrm{z}$ reaktora stała różnica temperatury była rejestrowana
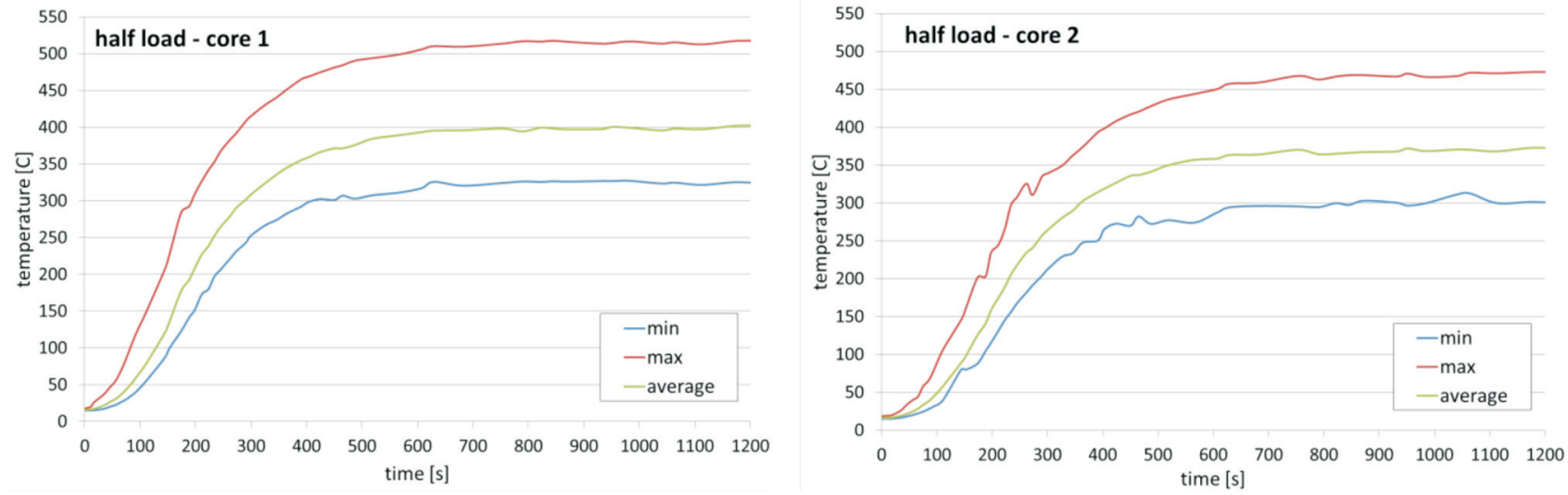

Fig. 4. Temperature of catalytic converter cores during heating of engine with load $30 \mathrm{~N} \cdot \mathrm{m}$, engine speed $30001 / \mathrm{min}$ Rys. 4. Temperatura rdzeni reaktora katalitycznego przy nagrzewaniu silnika z obciązeniem $30 \mathrm{~N} \cdot \mathrm{m}$ i prędkością obrotowa $30001 /$ min 
analysis, all temperatures were lower by $30-60 \mathrm{~K}$ than for the first support.

The temperature values on the thermograms are much lower than the temperature of the exhaust gas. The temperature of the pipe upstream of the catalytic converter, at the point where the thermocouple was fitted, was $110-150 \mathrm{~K}$ lower than the temperature of the exhaust gas measured at this point. When measuring the temperature on the surface of the catalytic converter, the heat transfer coefficient is made of a greater number of components (heat transfer coefficients of the casing, the insulation, the supports, heat penetration coefficients of the gases) than for the non-insulated pipe (additionally the material of the support has high heat capacity). All this renders the results of the thermographic analysis incomparable with the values of the exhaust gas temperatures, but the qualitative changes of the temperature increment in time (curve inclination) are the same, depending on the engine load. The possibility to record the temperature distribution at the same time on the entire surface of the converter allows for observing differences in the heating level of the supports resulting from their serial location in the converter casing. Insulation mats have been attached on the surface of both supports, which additionally reduce the amount of radiated energy and the occurrence of the same layers does not influence the value of the temperature difference. A more detailed analysis of the temperature distribution on the surface of the supports is not possible. The temperature distribution on the surface of the diffuser, the gap between the supports and the confuser have been analyzed and compared with the values for the supports bearing in mind that in these parts of the converter the exhaust gas has direct contact with the casing. The columns in Fig. 5 show the value of the maximum, minimum and average temperatures for five distinguished surfaces of the converter, for both states of engine operation (already heated).

For the maximum temperatures read from the thermograms, the influence of the insulation mats is negligibly low. It is caused by the fact that the highest temperature values occur on the edges of the supports i.e. in the spots where the mats are in direct contact with the exhaust gas, which causes their faster heating as seen in the thermographic images in Fig. 6. Taking the average and minimum values into account, the influence of the mats is much more conspicuous, particularly for the first support, for which these values are much lower than for the gap immediately behind it.

Figure 6 contains selected thermographic images with their comparison taken on idle (left) and loaded (right) engine for the same moment of measurement. The application of different temperature scales was necessary due to a high heat level of the catalytic supports (depending on the engine load). In individual images, we can clearly see differences in the heating level of individual elements including the influence of the number and heat conductance of layers in a given part of the catalytic converter. Selected images taken during the measurements for a given operating dla biegu jałowego od $700 \mathrm{~s}$, a dla silnika obciążonego od około $540 \mathrm{~s}$, natomiast stałe wartości temperatury dla trzech analizowanych punktów układu wylotowego ustaliły się dla biegu jałowego po około 940 s, a dla obciążonego silnika po około $540 \mathrm{~s}$.

Wykresy na rysunkach 3 i 4 przedstawiają wartości temperatury pochodzące $\mathrm{z}$ pomiarów przeprowadzonych przy użyciu kamery termowizyjnej, wykonywanych równolegle z pomiarami termoparami. Na termogramach wydzielano obszary odpowiadające powierzchnią każdemu z dwóch rdzeni mieszczących się w obudowie reaktora katalitycznego i odczytywano wartości maksymalną, minimalną oraz średnią dla danej powierzchni. Rozkład temperatury nie był równomierny, stąd wartości średnie są przesunięte w kierunku wartości minimalnych. Dodatkowo, według tej samej procedury, odczytano odpowiednio wartości temperatury na powierzchni dyfuzora wlotowego, konfuzora wylotowego oraz powierzchni szczeliny między rdzeniami.

Stabilizacja wartości na powierzchniach obu rdzeni następowała po tym samym czasie, przy czym dla silnika pracującego na biegu jałowym wystąpiło to po około 900 $\mathrm{s}$, a dla silnika pracującego z obciążeniem po około $700 \mathrm{~s}$. Jednocześnie dla drugiego rdzenia, w całym analizowanym przedziale czasowym, wszystkie wartości temperatury były mniejsze o 30-60 K niż dla pierwszego rdzenia.

Wartości temperatury pochodzące $\mathrm{z}$ termogramów są znacznie mniejsze niż temperatura spalin. Przykładowo, temperatura powierzchni rury przed reaktorem katalitycznym, w miejscu, gdzie była zamontowana termopara, była o 110-150 K mniejsza od temperatury spalin mierzonej w tym punkcie. Przy pomiarze temperatury na powierzchni reaktora katalitycznego współczynnik przenikania ciepła jest złożony z większej liczby składników (współczynniki przewodzenia ciepła obudowy, maty izolujące, rdzenie o budowie kanalikowej, współczynniki wnikania ciepła gazów) niż dla nieizolowanej rury, a dodatkowo materiał rdzeni ma dużą pojemność cieplną. Powoduje to, że wyniki $\mathrm{z}$ analizy termograficznej nie nadają się do bezpośredniego konfrontowania $\mathrm{z}$ wartościami temperatury spalin, natomiast jakościowo zmiany przyrostu temperatury w czasie (nachylenie krzywych) mają tożsamy charakter, zależny od obciążenia silnika. Możliwość rejestracji rozkładu temperatury w tej samej chwili na powierzchni całego reaktora pozwala również zaobserwować różnice w stopniu nagrzania rdzeni, wynikające $\mathrm{z}$ ich szeregowego umieszczenia w obudowie reaktora. Na powierzchni obu rdzeni znajdują się maty izolujące, które dodatkowo ograniczają ilość wypromieniowanej energii, niemniej jednak występowanie tych samych warstw powoduje, że nie ma to wpływu na wartość różnicy temperatury. Ale już bardziej szczegółowa analiza rozkładu temperatury na powierzchni rdzeni nie jest możliwa. Ponieważ przeanalizowano także rozkład temperatury na powierzchniach dyfuzora, szczeliny znajdującej się pomiędzy rdzeniami oraz konfuzora, porównano je z wartościami dla rdzeni, mając na uwadze, że w tych częściach reaktora spaliny mają bezpośredni kontakt z obudową. Wykresy na rysunku 5 przedstawiają wartości temperatury maksymalnej, 
mode of the engine separated by time intervals, present the changes of the temperature distribution in time for given surfaces, thus providing the qualitative picture of the device heating process. When analyzing the thermographic images one needs to note that different state of the surface and its curvatures and shape variations may distort the energy radiated by the device. In the images presented in this paper such a phenomenon is clearly visible in the initial part of the outlet confuser, which may have influenced the qualitative analysis whose results have been presented in Fig. 5.

\section{Conclusions}

The process of heating of a catalytic converter on a test stand under given operating conditions is faster because the cooling action of the air flowing around its outer parts is eliminated.

The engine operating parameters influence the exhaust gas temperature and the operating conditions of the catalytic converter defined by the heating time of the device (the time to reach light-off) and the temperature of the already heated converter. It is thus recommended that after engine cold start, it should immediately start operation under partial load.

The thermographic analysis of the catalytic converter on the test stand was difficult due to a limited access to the devices resulting from the fitting method. The insulation mats fitted between the supports and the converter casing influenced the distribution of temperature on the surface of the device. The amount of heat radiated outside will always be lower than the actual heat inside the converter (thermographic measurements are a qualitative method whose main advantage is non-invasiveness). Nevertheless, the nature of changes of the exhaust gas temperature and the temperature measured on the surface of the converter was the same, which results from the engine operating conditions. Thermographic images show the differences in the heating level of the supports and changes in the temperature distribution in time for the catalytic converter.

a)

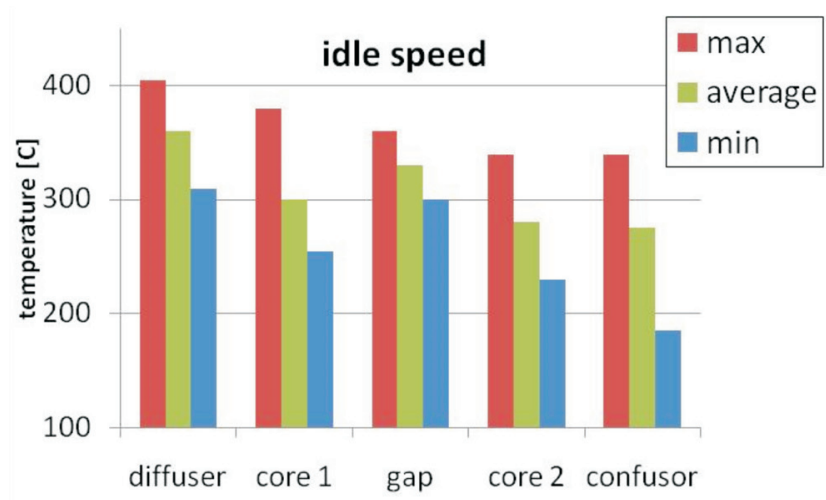

minimalnej oraz średniej, kolejno dla pięciu wyodrębnionych powierzchni reaktora katalitycznego, dla obu stanów pracy silnika już nagrzanego.

Przy maksymalnych wartościach temperatury odczytanych z termogramów wpływ mat izolujących jest mały, prawie pomijalny. Jednak jest to spowodowane tym, że największe wartości temperatury występują na brzegach rdzeni, tak więc w miejscach, gdzie maty mają bezpośredni kontakt ze spalinami, w związku z czym szybciej się nagrzewają, co jest dobrze widoczne na obrazach termograficznych (rys. 6). Gdy uwzględnia się wartości średnie i minimalne, wpływ mat jest dużo bardziej widoczny, szczególnie dla rdzenia pierwszego, dla którego wartości te są znacznie mniejsze niż dla szczeliny znajdującej się bezpośrednio za nim.

Na rysunku 6 zamieszczono wybrane zdjęcia termograficzne, zestawiając obok siebie obrazy wykonane podczas pracy silnika na biegu jałowym (z lewej strony) oraz pracy silnika obciążonego (z prawej strony) dla tej samej chwili pomiaru. Konieczne było zastosowanie różnych skal temperaturowych, ze względu na różny stopień nagrzania rdzeni reaktora w zależności od obciążenia silnika. W obrębie poszczególnych zdjęć wyraźnie widoczne są różnice w stopniu nagrzania poszczególnych elementów, w tym oddziaływanie ilości i przewodności warstw znajdujących się w danej części reaktora katalitycznego. Wybrane obrazy pochodzące $\mathrm{z}$ pomiarów dla danego trybu pracy silnika rozdzielone interwałami czasowymi prezentują następujące w czasie zmiany rozkładu temperatury dla określonych powierzchni, dając jakościowy obraz procesu nagrzewania urządzenia. Analizując obrazy termograficzne, należy również mieć na uwadze, że różny stan powierzchni oraz jej załamania i zmiany kształtu mogą wprowadzać zakłócenia w rozkładzie wypromieniowanej przez ciało energii. Na zamieszczonych $\mathrm{w}$ pracy obrazach zjawisko takie jest dobrze widoczne w początkowej części konfuzora wylotowego, co mogło mieć wpływ na analizę ilościową, której wyniki są zawarte na wykresach (rys. 5).

b)

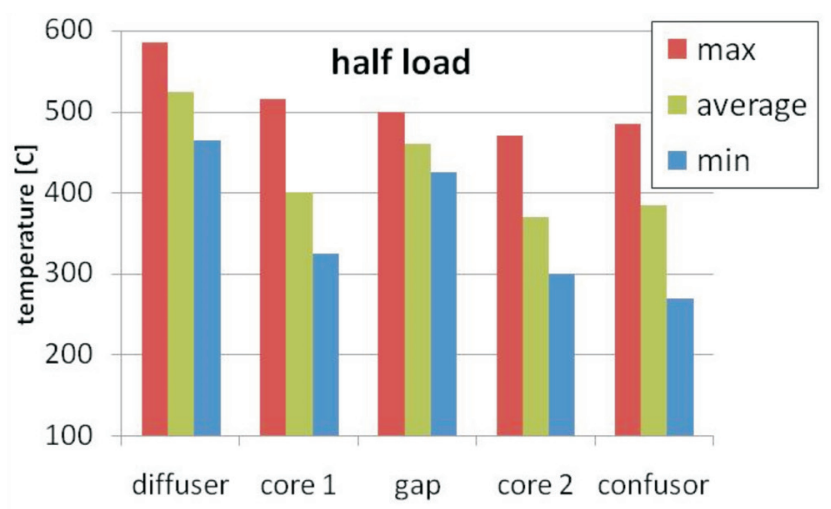

Fig. 5. Surface temperature of the catalytic converter elements for heated engine: a) idle speed, engine speed $20001 / \mathrm{min}, \mathrm{b}) \mathrm{load} 30 \mathrm{~N} \cdot \mathrm{m}$, engine speed $30001 / \mathrm{min}$

Rys. 5. Temperatura powierzchni elementów reaktora katalitycznego dla silnika nagrzanego: a) bieg jałowy z prędkością obrotowa 2000 1/min, b) obciążenie $30 \mathrm{~N} \cdot \mathrm{m}$, prędkość obrotowa $3000 \mathrm{l} / \mathrm{min}$ 
b)
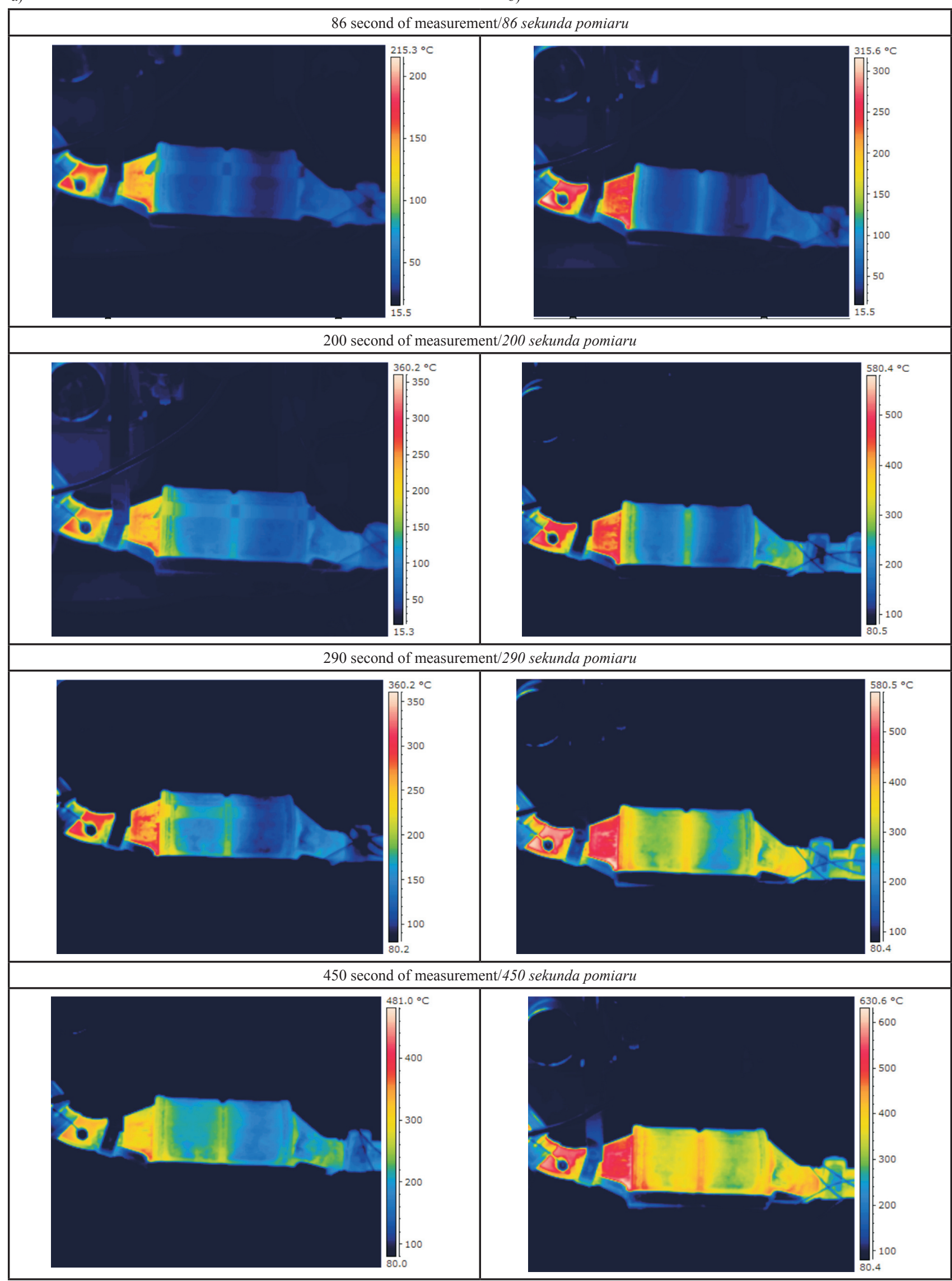

Fig. 6. Thermogram photos selected from measurements: a) idle speed, engine speed $2000 \mathrm{1} / \mathrm{min}$, b) load $30 \mathrm{~N} \cdot \mathrm{m}$, engine speed $30001 / \mathrm{min}$ Rys. 6. Wybrane z pomiarów obrazy termograficzne: bieg jałowy z prędkością obrotowa 2000 1/min; obciażenie $30 \mathrm{~N}$ ·m, prędkość obrotowa 3000 1/min 
a)

b)
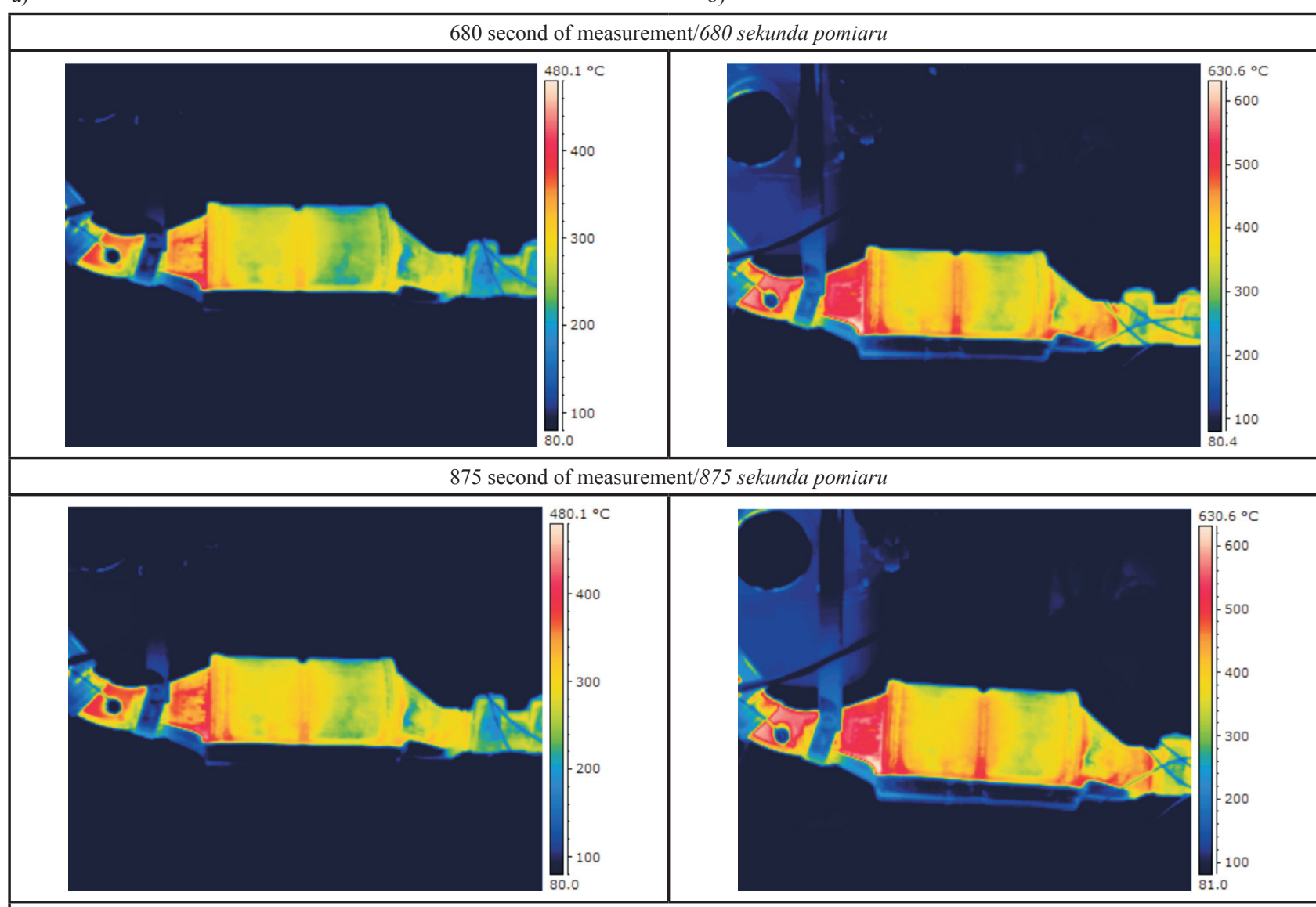

1040 second of measurement/1040 sekunda pomiaru

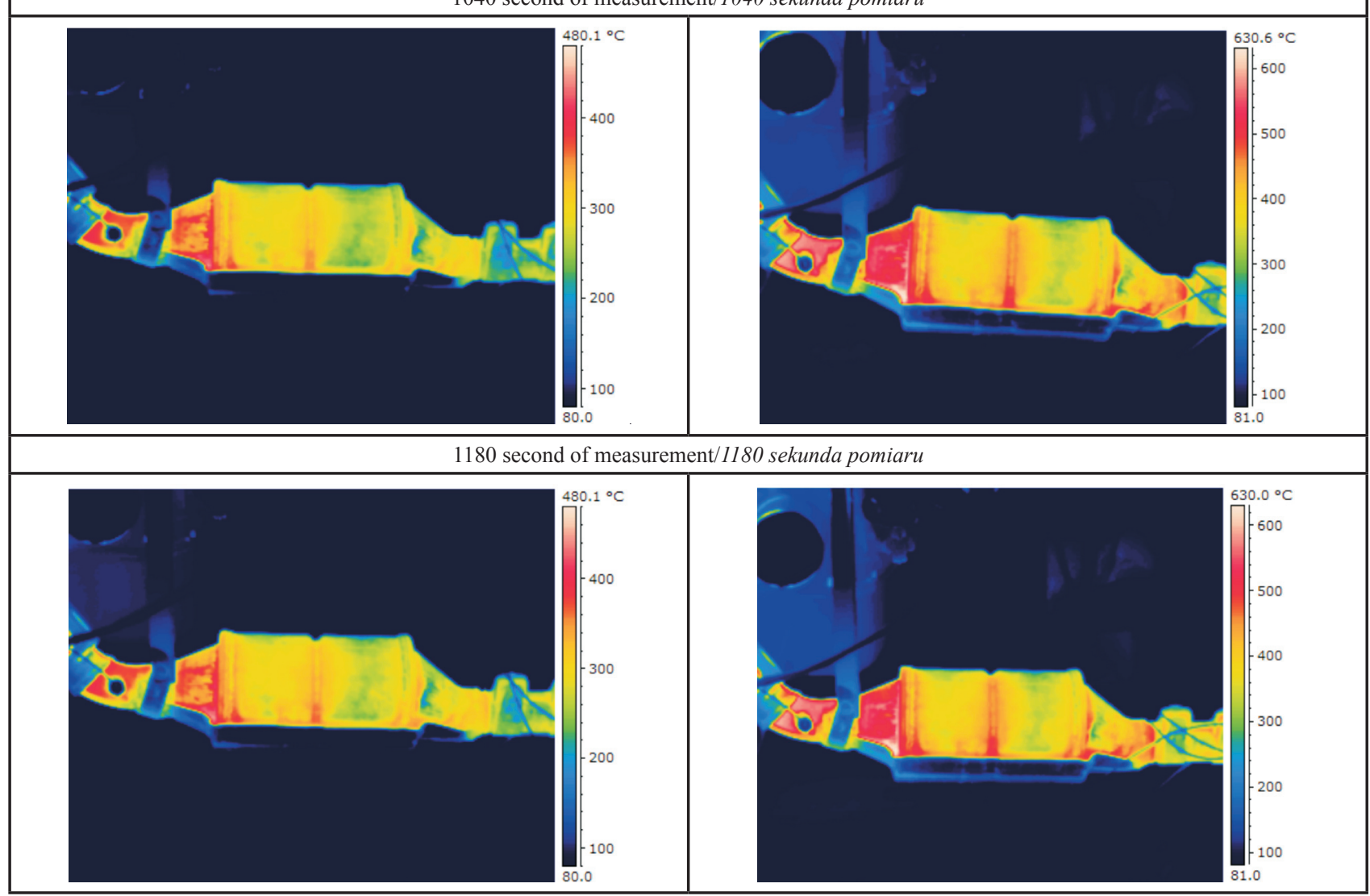

Fig. 6cont. Thermogram photos selected from measurements: a) idle speed, engine speed 2000 1/min, b) load $30 \mathrm{~N} \cdot \mathrm{m}$, engine speed 3000 1/min Rys. 6cd. Wybrane z pomiarów obrazy termograficzne: bieg jałowy z prędkością obrotowa 2000 1/min; obciażenie $30 \mathrm{~N}$ ·m, prędkość obrotowa 3000 1/min 


\section{Bibliography/Literatura}

[1] Bielaczyc P., Merkisz J., Pielecha J. Stan cieplny silnika spalinowego a emisja związków szkodliwych. Wydawnictwo Politechniki Poznańskiej, Poznań 2001.

[2] Brzeżański M. Emisja toksycznych składników spalin $\mathrm{w}$ fazie nagrzewania się silnika o zapłonie iskrowym z zastosowaniem akumulatora ciepła. Wydawnictwo Politechniki Krakowskiej, Kraków 2007.

[3] Damijan Z., Uhryński A. Systemic cryotherapy influence of low temperatures on selected physiological parameters. Acta Physica Polonica A, 1-A (121), 2012, A-38-A-41.

[4] Damijan Z., Uhryński A. The influence of driver's working environment on thermical changes of their organism Acta Physica Polonica A, 1 (118), 2010, 35-40.

[5] Jakubowska T., Peszyński-Drews C., Więcek B. Standaryzacja $\mathrm{w}$ badaniach termograficznych $\mathrm{w}$ zastosowaniu praktycznym na przykładzie pracowni termograficznej w Centrum Diagnostyki i Terapii Laserowej Politechniki Łódzkiej. Acta Bio-Optica et InformaticaMedica, 2 (12), 2006, 81-84.

[6] Kruczyński S. Trójfunkcyjne reaktory katalityczne. Wydawnictwo ITE, Warszawa-Radom 2004.

[7] Kruczyński S. Eksploatacja trójfunkcyjnych reaktorów katalitycznych - dezaktywacja termiczna. Eksploatacja i Niezawodność, 3 (2014), 2012.

[8] Lepiarczyk D., Gawędzki W., Uhryński A., Tarnowski J. Usage of thermo-vision in research concerning kinematic pair of friction in machines and mechanical devices. Vísnik Kiïvs'kogo Nacional'nogo Universitetu Tehnologij ta Dizajnu, 3, 2012, 190-195.

[9] Lepiarczyk D., Uhryński A. Thermo-vision analysis of iron foundry production process concerning secondary usage of heat. Polish Journal of Environmental Studies, 3 (23), 2014, 1017-1023.

[10]Mitianiec W. Termochemiczny model katalizatora w układzie wylotowym silnika dwusuwowego. Journal of KONES, 1-2 (7), 2000.

[11]Rybarz M., Brzeżański M. Zagadnienia tworzenia się kondensatu w układzie wylotowym silnika spalinowego. Czasopismo Techniczne Mechanika, 8-M, 2008.

[12]Więcek B., Mey G. Termowizja w podczerwieni: podstawy i zastosowania, Wydawnictwo PAK, Warszawa 2011.

\section{Wnioski}

Proces nagrzewania reaktora katalitycznego na stanowisku silnikowym, w danych warunkach pracy silnika, będzie następował szybciej, gdyż wyeliminowane jest chłodzące oddziaływanie powietrza opływającego zewnętrzne powierzchnie reaktora, wymuszone ruchem pojazdu.

Parametry pracy silnika mają wpływ na temperaturę spalin, a przez to również na warunki pracy reaktora katalitycznego, definiowane przez czas nagrzewania urządzenia, a w związku z tym - czas potrzebny do uzyskania minimalnej temperatury pracy oraz temperaturę pracy reaktora już nagrzanego. $Z$ tego względu bezpośrednio po zimnym rozruchu silnika korzystne jest, aby pracował on z częściowym obciążeniem.

Analiza termowizyjna reaktora katalitycznego na stanowisku silnikowym była utrudniona ze względu na ograniczony dostęp wynikający ze sposobu montażu. Dodatkowo maty izolujące znajdujące się pomiędzy rdzeniami a obudową reaktora miały wpływ na rozkład temperatury na powierzchni reaktora. Wypromieniowana na zewnątrz ilość ciepła zawsze będzie mniejsza od rzeczywistej wewnątrz urządzenia, dlatego pomiary termowizyjne są metodą jakościową, a nie ilościową, której główną zaletę jest bezinwazyjność. Niemniej jednak charakter zmian temperatury spalin i temperatury zmierzonej na powierzchni reaktora był tożsamy, wynikający z warunków pracy silnika. Zdjęcia termograficzne obrazują różnice w stopniu nagrzania rdzeni oraz zmiany rozkładu temperatury w czasie dla reaktora katalitycznego.

[13]Wiśniewski S. Wymiana ciepła. WNT, Warszawa 1997

[14]Worsztynowicz B. Bilans cieplny silników spalinowych typu heavy-duty w aspekcie norm emisji. Silniki spalinowe i ekologia - opracowanie monograficzne. Wydawnictwo Politechniki Krakowskiej, Kraków 2014.
Barbara Worsztynowicz, DEng. - Doctor in the Faculty of Mechanical Engineering and Robotics at AGH University of Science and Technology.

Dr inż. Barbara Worsztynowicz - adiunkt na Wydziale Inżynierii Mechanicznej i Robotyki w Akademii Górniczo-Hutniczej w Krakowie.

e-mail:worsztyn@agh.edu.pl

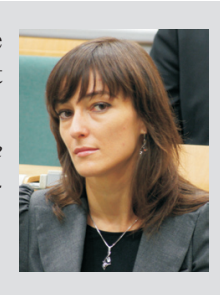

Andrzej Uhryński, DEng. - Doctor in the Faculty of Mechanical Engineering and Robotics at AGH University of Science and Technology.

Dr inż. Andrzej Uhryński - adiunkt na Wydziale Inżynierii Mechanicznej i Robotyki w Akademii GórniczoHutniczej w Krakowie.

e-mail: uhrynski@agh.edu.pl 